\title{
A EXPEDIÇÃO MONTAIGNE: UMA LEITURA SOB O VIÉS PÓS-MODERNO
}

Francisco das Chagas Souza Costa ${ }^{1}$

Resumo: Causador de celeumas até no tocante à data de seu nascimento, o movimento artísticocultural denominado de pós-modernismo traz em seu bojo uma série de alterações estéticas as quais não deixam de refletir algumas posições ideológicas que parecem ganhar novas configurações, mas não escapam do inevitável diálogo com o passado. É nessa perspectiva que o presente artigo se propõe a fazer uma leitura do romance A Expedição Montaigne (1982) de Antônio Callado. Situada no contexto pós-moderno, a referida obra faz uma releitura de um aspecto crucial na formação da identidade nacional (a figura do índio) o qual já foi matéria de debate para românticos e modernistas. Nesse sentido, buscar-se-á, na diegese proposta por Callado, os indícios de inovações do fazer literário desses novos tempos. Ademais, as próprias posições teóricas não consensuais em torno do pós-modernismo merecem ser ressaltadas a partir do artefato que se queira analisar. Entre outras coisas, são essas as razões que justificam e direcionam esse trabalho. Nazário (2008), Jameson (2006), Eagleton (1998), Hall (2005), entre outros, servem como suporte teórico para o desenvolvimento deste artigo.

Palavras-chave: A Expedição Montaigne. Ideologia. Pós-modernismo.

\section{Introdução}

É recorrente, em tempos atuais, a ideia de que existem indícios consistentes para se pensar que o ser humano vive um momento sui generis no qual as incertezas das mais diversas ordens têm se sobressaído em relação às doutrinas ou dogmas assertivos do passado instaurado pela chamada modernidade. Diante disso, é constatado que no mundo contemporâneo paira um sentimento, cada vez mais acentuado, de descrença num futuro sadio e harmonioso. Embora a religião ainda sobreviva, como um dos últimos redutos de esperança humana, as novas gerações, sobretudo nas áreas mais urbanizadas, parecem vivenciar uma perspectiva de vida mais cética quanto a princípios norteadores da sua existência.

Nessa esteira de pensamento, não se pode prescindir de ressaltar uma situação no mínimo paradoxal: a sociedade capitalista atingiu níveis inimagináveis nas questões materiais (pelos menos em termos absolutos), mas se mostra cada

\footnotetext{
${ }_{1}^{1}$ Doutorando em Letras pelo Programa de Pós-Graduação em Letras, PPGL, da Universidade do Estado do Rio Grande do Norte.
}

Revista de Letras JUÇARA, Caxias - Maranhão, v. 03, n. 01, p. 100 - 121, ago. 2019 | 100 
vez mais angustiada. Ou seja, parece haver uma carência de conceitos e valores os quais acabam sendo esfacelados, talvez, por falta de bases sólidas.

O ideal de modernidade, tendo como base o pensamento iluminista, a guinada da ciência e o processo de industrialização, trouxe por um lado alguns avanços no tocante ao pensamento livre e a uma situação de produção de bens nunca antes vistos. Em outra perspectiva, as desigualdades sociais e a exploração do ser humano foram também ampliadas. Nesse sentido, as ideias marxistas não tiveram a menor chance de se concretizarem como poderia supor os seus entusiastas mais radicais. Na luta entre capital e social, o poder econômico venceu com vasta margem de vantagem. O corolário desse resultado é uma sociedade que se modela sem ideais fixos ou homogêneos, o que pode ser interpretado como algo temerário para os mais conservadores ou como a única saída para os chamados neomarxistas. Conforme Jameson (2006), é possível afirmar que:

\begin{abstract}
Os últimos anos têm sido marcados por milenarismo invertido segundo o qual os prognósticos, catastróficos ou redencionistas, a respeito do futuro foram substituídos por decretos sobre o fim disto ou daquilo (fim da ideologia, da arte, ou das classes sociais; a "crise" do leninismo, da social democracia, ou do Estado do bem-estar etc.); Em conjunto, é possível que tudo isso configure o que se denomina, cada vez mais frequentemente, pós-modernismo. (2006, p.27)
\end{abstract}

Nessa lógica, e na condição de fenômeno sociocultural, o referido movimento, ratificado nas palavras de Jameson (2006), reverbera com intensidade considerável no mundo das artes e por consequência no fazer literário. Controversa por natureza, essa perspectiva de compreensão da sociedade contemporânea precisa ser analisada de modo que sejam ponderadas as relações entre o passado (tradicional, clássico etc) e os tempos hodiernos com suas inovações estéticoideológicas.

Com isso, o interesse desse conjunto de ideias é compreender como o pensamento pós-moderno se configura na produção literária. Para isso, faz-se uma leitura do romance "A Expedição Montaigne" (1982) do escritor Antônio Callado. O estudo da referida obra terá por finalidade precípua a análise de aspectos estéticos e ideológicos que possam ter uma relação com essa nova realidade da prosa contemporânea, o que não significa, necessariamente, uma ruptura cabal em 
relação aos escritos da literatura moderna. Parece não ser censurável a ideia de que a arte literária escapa a restrições de caráter temporal, uma vez que o interno e externo de uma obra extrapolam um fator histórico condicionante. Desse modo, postular que "A Expedição Montaigne" é pós-moderna só porque surgiu nas últimas década do século XX, é tão leviano quanto afirmar que o fenômeno pós-moderno e sua repercussão na sociedade não passaria de uma ilusão de ótica.

Nesse sentido, sem o equívoco de um julgamento de valor quanto à representação da obra com traços pós-moderno em relação a outras situadas no Romantismo e/ou Modernismo, por exemplo, é salutar compreender a perspectiva pós-moderna como uma circunstância que emerge na sociedade para depois adquirir o formato pragmático nas artes e teórico no mundo acadêmico.

Uma das constatações basilares dessa época é a de que o ser humano está em crise quanto à sua identidade da mesma forma que a fé no progresso entrou em decadência. Assim, o pós-modernismo no âmbito literário é apenas uma das possibilidades de se apreciar essa fluidez de valores e sentimentos experimentados pela humanidade hodierna.

Seguindo tal lógica, a obra "A Expedição Montaigne" parece trazer elementos interessantes para se entender parte da configuração da ótica pósmoderna. Esse romance calladiano dialoga com um passado que remete à fundação da nação brasileira ao apresentar de modo destacado a figura do índio, nativo que teria sido usurpado por um colonizador cruel. De modo sarcástico e irônico, o narrador desconstrói a identidade do "bom selvagem", marketing do Romantismo já contestado, ao seu modo, pelos modernistas.

Associado ao personagem indígena, a presença de um jornalista (Vicentino Beirão), influenciado pela cultura francesa, surge com o ideal de devolver aos índios tudo o que os colonizadores haviam tirado. O índio (Ipavu) e o jornalista afrancesado compõem uma prosa quixotesca pós-moderna na medida em que os limites do ridículo, do irônico e da própria noção do que seja ético são rompidos de maneira ímpar. Resta, talvez, ao leitor (nas partes finais do livro) dar gargalhadas com a imagem de homem sendo queimado na fogueira (Vicentino Beirão) devido à canalhice cometida pela versão pós-moderna do "Sancho Pança" (Ipavu).

Com o objetivo de sistematizar os aspectos teóricos e a análise literária no tocante à obra supracitada, além dessas palavras introdutórias, tem-se um primeiro 
tópico que almeja discutir alguns posicionamentos e fatos do chamado pósmodernismo. A segunda parte pretende realizar uma análise do romance "A Expedição Montaigne" sob a ótica pós-moderna e, por fim, as considerações finais apresentam um arremate das ideias postas, mas sem um teor propriamente conclusivo.

\section{O pós-moderno: aporias e ideologias}

Distinguir épocas históricas associando-as, também, aos chamados movimentos artístico-literários não deixa de trazer, na sua essência, o surgimento e/ou a reformulação de certos aspectos ideológicos, o que gera como resultado, quase imperativo, algumas alterações na própria estética. O caso do pós-moderno parece ter uma peculiaridade ao apresentar uma proposta, mesmo inexequível pragmaticamente, de aversão a um engajamento ideológico específico e/ou a um padrão formal mais nítido, a exemplo do que se via em outros tempos. Quer dizer, então, que o pós-moderno não se enquadra como escola literária da mesma forma que os seus antecessores? Sendo assim, ele seria o quê? Estaria acima do bem e do mal com a sua veia relativista? A aporia pela qual passa esse movimento é tão significativa quanto o debate entre aqueles que fazem apologia e os que apontam os equívocos.

Com isso, a dificuldade de definição do que seja pós-moderno talvez seja proposital, haja vista a busca de uma espécie de áurea que o diferencie de outros movimentos socioculturais. Nesse sentido, é possível citar dois aspectos que envolvem a concepção desse fenômeno: o histórico e a semântica do termo em si. $\mathrm{O}$ primeiro fator refere-se à data de surgimento de algo cuja paternidade ou maternidade ainda não foi reconhecida devido à própria natureza anárquica dessa perspectiva teórica no tocante à sociedade e à arte. Com o intuito de traçar um quadro histórico da ótica pós-moderna, Nazário (2008) elenca uma série de datas e fatos, mas sem uma posição definitiva que corrobore o exato momento de emersão desse movimento. A impossibilidade de estabelecer datas fixas, quase que obriga o teórico a uma questão aporética: "Como delimitar o quadro histórico do pós-modernismo se o seu conceito não se sustenta historicamente?" (Nazário, 2008, p.24). Assim, na sua enumeração, Nazário chama atenção para um detalhe 
crucial que compõe o modus operandi do pensamento pós-moderno: a quebra de qualquer hierarquia ou ordem. É isso que fica patente quando ele afirma:

\begin{abstract}
O happening não nasce em 1962, quando Yves Klenin salta de um edifício em Nice fotografando sua performance e chamando-a de Salto no Vazio, mas quando Gustave Courbert derruba, durante a Comuna de Paris, a Coluna Vendôme, símbolo fálico do império; ou quando Hans Arp assoa o nariz na bandeira da França, durante o serviço militar; ou ainda quando Jean-Pierre Dubrey apaga, com uma jato de urina, a "chama eterna" do Arco do Triunfo. Se algum crítico situa a morte da arte em 1964, quando Andy Warhol expõe sua recriação plástica da Caixa de Sabão Brillo, é porque se esquecem do assassinato cometido décadas antes por Marcel Duchamp ao apresentar um urinol como 'obra de arte' (NAZÁRIO, 2008, p.23-24)
\end{abstract}

As ações e os fatos supracitados que remetem diretamente à empreitada pós-moderna estão sujeitos a passarem pelo filtro de uma visão mais conservadora. É lógico, nesse sentido, que pessoas que valorizam uma concepção mais tradicional de arte e o respeito às hierarquias construídas socialmente, não hesitariam em dizer que a postura pós-moderna traz uma subversão perniciosa que precisaria ser evitada para o bem da sociedade. Por outro lado, os defensores da visão pós-moderna têm o argumento de que a sociedade já esgotou todas as suas esperanças e que não existiria outro caminho a não ser o rompimento de normas institucionais que aprisionaram o ser humano a modelos de convivência e concepções artísticas que necessitam ser revistos não importando a anarquia posta como substituição.

Portanto, não se pode negar que do ponto de vista social, cultural e político, há indivíduos que se antagonizam no tocante não só ao conceito de pósmodernismo, mas nas implicações mais pragmáticas que ele possa reverberar na sociedade. Relembrando os conceitos de direita e esquerda da Revolução Francesa (o que não é démodé), é plausível postular que os direitistas (conservadores) enxergam o pós-moderno como a leviana e última cartada de uma esquerda que ao não derrotar o capitalismo tenta transformá-lo em um monstro e para isso não hesita em comprometer toda a sociedade. Já a nova esquerda não deixa de apontar o lado desumano do viés capitalista que pela sua conduta pouco altruísta seria o responsável pelo recrudescimento da queda do ser humano que agora vive sem princípios e valores éticos e estéticos.

Revista de Letras JUÇARA, Caxias - Maranhão, v. 03, n. 01, p. 100 - 121, ago. 2019|104 
Essa compreensão eminentemente política do pós-modernismo é relevante na medida em que é postulado um movimento, que envolve vários aspectos da cultura e da sociedade, como se fosse desprovido de teor ideológico, o que constitui uma falácia. É óbvio, no entanto, que o simples fato de afirmar não pertencer a nenhuma ideologia ou de não ter posição política definida, revela uma postura político-ideológica assim como o ateu demonstra, em sua descrença, algum tipo de crença. Ou seja, "qualquer ponto de vista a respeito do pós-modernismo na cultura é ao mesmo tempo, necessariamente, uma posição política, implícita ou explícita, com respeito à natureza do capitalismo multinacional em nossos dias" (Jameson, 2006, p.29). Logo, ao que parece, o pensamento pós-moderno por negar uma essência ou uma ideia que posa ser universalizada, tenta esconder alguns dos seus aspectos que são, quase de imediato, revelados pelos que se colocam como antagonistas.

Nesse ponto, se insere o segundo fator (dito anteriormente) na busca da concepção do pós-modernismo: a semântica do termo em si. O prefixo pós relacionado ao termo principal, modernismo, mesmo sem a pretensão aparente, traz o sentido de algo novo, o que para alguns poderia representar a superação do que se entendia por moderno. Sendo mais radical, poder-se-ia dizer que o pósmodernismo, pela sua natureza anárquica e popular seria a antítese de um modernismo hierárquico e elitista. Todavia, alguns pensadores dão uma espécie de baixada de tom numa suposta arrogância pós-moderna. Luiz Nazário (2008) defende a impossibilidade de um movimento artístico-cultural que inove sem as bases de uma tradição. As mudanças estéticas pós-modernas, portanto, seriam reinterpretações de uma cultura mais antiga não podendo ser posta como superior. No âmbito ideológico, ele faz uma constatação ainda mais contundente:

Cabe perguntar até que ponto o pós-modernismo não passa de uma mistificação ideológica, ao pressupor uma superação da modernidade que não se realizou em parte alguma. Nem nos países mais avançados a informatização da sociedade e a robotização da produção libertaram o homem do trabalho alienado ou substituíram as relações reprodutivas por relações eróticas. Mais ignorantes do que nunca, apesar de mergulhadas num oceano de informações, as elites contemporâneas refugiam-se nos shoping centers enquanto os trabalhadores, tornados supérfluos pela automação, são desempregados em massa e empurrados para a criminalidade. (NAZÁRIO, 2008, p.24) 
Os argumentos de Nazário (2008) se conduzem numa tentativa de desconstrução da ideia de que o aspecto pós-moderno seria a superação do modernismo. E mais, o crítico analisa que o prefixo pós só faria sentido como algo negativo, ou seja, seria o indício de que o pós-moderno superaria todos os males realizados nos tempos modernos. Para ser mais enfático, é possível supor que "a época 'pós-moderna' teria sido, então, efetivamente inaugurada em 1945, com a revelação mundial dos campos de extermínios nazistas e a explosão da bomba atômica em Hiroshima e Nagasaki" (NAZÁRIO, 2008, p. 25).

Se a leitura de Nazário (2008) pode, a princípio, desagradar os mais entusiasmados com a ótica pós-moderna, Compagnon (2003), na mesma tônica, não se recusa a apontar os paradoxos de uma corrente de pensamento que é problemática desde a sua própria formatação conceitual. Para ele, o pós-moderno é controverso pela pretensão equivocada de se apresentar como uma antítese à ideologia moderna. Ao fazer questionamentos acerca da ideia de pós-moderno, o teórico francês acaba colocando o movimento numa situação de impasse:

\begin{abstract}
Se o moderno é o atual e o presente, o que significa o prefixo pós-? Não seria ele contraditório? $\mathrm{O}$ que seria esse depois da modernidade, designado pelo prefixo, se a modernidade é a inovação constante, o próprio movimento do tempo? Como é possível falar de um tempo depois do tempo? Como pode um presente negar a sua qualidade de presente? Responderemos provisoriamente que o pós-moderno é antes de tudo uma palavra de ordem polêmica, posicionando-se enganosamente contra a ideologia da modernidade ou contra a modernidade como ideologia ( COMPAGNON, 2003, p.103)
\end{abstract}

Não obstante exponha algumas controvérsias em torno do próprio conceito de pós-moderno, Compagnon pondera no tocante a fatos e características que foram postos, ao longo do tempo, por alguns pensadores que refletiram acerca desse fenômeno. Ao citar pontos negativos e positivos, o autor de Demônio da Teoria consegue chegar a uma síntese: o pensamento pós-moderno não se sustenta teórica e ideologicamente quando pretende atingir o ápice do que se considera inovação. Em outras palavras, "o pós-moderno contém um paradoxo flagrante: pretende acabar com o moderno, mas, no romper como ele, reproduz a operação moderna por excelência: a ruptura" (COMPAGNON, 2003, p.105). 
Com isso, o não entusiasmo de Compagnon com a nova moda pósmoderna parece se fundamentar na ideia de que esse movimento em vez de ser uma ruptura cabal em relação às práticas modernas, configura-se apenas como uma continuidade na qual os sujeitos se sentem, talvez, mais livres para suas criações.

A conclusão do referido teórico, nesse sentido, é de que tal liberdade no processo criativo das artes, por exemplo, não é tão recente e nem sempre está sujeita a um uso razoável. Ou seja, o ser humano pode não estar devidamente apto para ações quando se julga inteiramente livre.

De modo distinto, Jameson (2006) percebe a ascensão do fenômeno pósmoderno como o resultado do esgotamento das ações modernas que já não davam conta de uma nova realidade. O capitalismo, nessa ótica, atingiu a zênite de sua empreitada em busca dos bens materiais, o que refletiu numa sociedade que não tem mais saciado o prazer nos produtos que são oferecidos. Como quase tudo é descartável, efêmero e substituível, o indivíduo se torna com uma identidade fluida, heterogênea e anárquica.

Sendo assim, reconhecendo, antes de tudo, a proeminência pós-moderna na arquitetura, Jameson (2006) defende que o modernismo tinha como base uma visão elitista e autoritária em relação ao futuro da sociedade. O que veio depois, portanto, teria que, inevitavelmente, romper as fronteiras entre a cultura de massa e a chamada alta cultura. Nas palavras do teórico, ocorre que:

\begin{abstract}
Os pós-modernismos têm revelado um enorme fascínio justamente por essa paisagem "degradada" do brega e do Kitsch, dos seriados e da cultura Reader's Digests, dos anúncios e dos motéis, dos late shows e dos filmes B hollywooodianos, da assim chamada paraliteratura - com seus bolsilivros de aeroporto e suas subcategorias do romanesco e do gótico, da biografia popular, histórias de mistérios e assassinatos, ficção científica e romances de fantasia: todos esses materiais não mais apenas "citados", como o poderiam fazer um Joyce ou Mahler, mas são incorporados à sua própria substância. (JAMESON, 2006, p.28)
\end{abstract}

Essas metamorfoses nas produções artísticas e na própria concepção do que seja arte, é para Jameson, o resultado de uma nova fase da sociedade capitalista. Ou seja, superadas as utopias marxistas, o conceito de lutas de classes não faz mais sentido no contexto de um mundo globalizado e pós-industrial. $O$ pensamento pós-moderno seria, desse modo, um reflexo cultural de um novo 
conjunto de relações sociais, que mesmo não lançando fora, cabalmente, o passado, se conduzem por rotas estéticas e ideológicas pouco ortodoxas e tampouco sujeitas a hierarquias ou conceitos fixos.

$\mathrm{Na}$ contramão do discurso apologético feito por Jameson, Eagleton (1998) apresenta um libelo que procura apresentar uma série de equívocos que sustentam a empreitada pós-moderna (por uma questão de síntese, é salutar discorrer acerca de dois exemplos: hierarquia e essencialismo). Um dos primeiros pilares atingidos pela argumentação do teórico inglês é a negação da hierarquia.

Para Eagleton, não existiria sociedade sem o estabelecimento de princípios hierárquicos os quais fazem os seres humanos realizar as escolhas de acordo com as suas prioridades. O relativismo pós-moderno, nesse caso, parece trazer no seu cerne a suspeita de que afirmar a superioridade de uma obra em relação a outra, por exemplo, faz parte de uma plataforma elitista. Sendo mais especifico, é possível dizer que "alguns radicais começam então a sentir-se ligeiramente enjoados da verdade autoevidente de que algumas questões ou artefatos valem mais que outros, e a confundir isso com 'elitismo'” (EAGLETON, 1998, p.95).

Ao ratificar que a sociedade não tem como prescindir de suas hierarquias e valores, o autor de "Teoria da Literatura: Uma Introdução" parte para outra refutação: o antiessencialismo pregado pela visão pós-moderna. Para ele, "o essencialismo é, na sua forma mais inócua, a doutrina que reza que as coisas se compõem de certas propriedades" (EAGLETON, 1998, p.97) as quais estão sujeitas a serem outras, caso sofram alterações radicais em uma ou mais propriedades. $\mathrm{O}$ essencialismo defendido por Eagleton não pressupõe que se tenha domínio categórico do princípio e do fim das coisas, mas de que não se pode relativizar excessivamente os objetos a ponto de se chegar a um esvaziamento completo de sentido ou lógica. Não obstante essa contestação, Eagleton acaba por dar certa razão ao pós-modernismo quando a visão essencialista é posta com radicalismo:

\footnotetext{
O pós-modernismo se opõe ao essencialismo; mas também se opõe às metanarrativas, à Razão universal e às culturas não pluralista, e essas visões possivelmente the são essenciais. Apesar de tudo isso, o antiessencialismo pós-modernista decerto merece crédito. Existem, com efeito, empregos redutivos, falsamente eternizantes, brutalmente homogeneizantes do conceito de essência, e eles causaram especial estrago nos campos da etnicidade e do gênero (EAGLETON, 1998, p.102).
} 
Desse modo, a ponderação do referido teórico conduz ao reconhecimento de que é inviável se postular, a priori, uma imutabilidade dos seres, como pode desejar um mau essencialismo. Da mesma forma, não se pode aceitar o pensamento de que as coisas podem ser mudadas por simples caprichos já que, pela própria natureza, têm intrínsecas certas essências. Em outras palavras, "não podemos alijar o essencialismo porque precisamos saber, entre outras coisas, que necessidades são essenciais para a humanidade e quais não são" (EAGLETON, 1998, p.103).

Em meio a essas controvérsias teóricas em que está envolvida a corrente pós-moderna, outro estudioso pode ser incluído no debate: Connor (2000). O tom desse crítico em relação ao pós-modernismo parece destoar daqueles que fazem apologia ou que são antagônicos. Não seria, na linguagem popular, "ficar em cima do muro", mas uma postura de quem analisa os fatos sem nenhum aparente apego ideológico mais radical. Na sua obra "Cultura Pós-moderna", especificamente no capítulo "Pós-modernismo e literatura", Connor (2000) procura estabelecer um paralelo mais preciso do viés pós-moderno com o fazer literário. Segundo o teórico, "a narrativa do declínio ou substituição do modernismo é talvez menos clara, mas não menos abrangente, nos estudos literários (CONNOR, 2000, p.87). Com isso se constata que nas demais artes e na arquitetura o fenômeno pós-moderno adquiriu, provavelmente, maior visibilidade uma vez que os meios e os modos de divulgação tenham sido mais objetivos e eficientes.

Contudo, Connor (2000) não nega que o movimento pós-moderno tenha encontrado na literatura um "terreno fértil" para a disseminação de suas ideias. A ponderação realizada, nesse caso, é acerca da polêmica ruptura como o modernismo. O teórico não entrar na discussão se o pós-moderno existe de fato ou, ainda, sobre sua repercussão boa ou má para a sociedade. Para ele, o pósmodernismo ocorre como uma consequência do modernismo que, talvez, tenha se aprofundado na sua gana de ruptura com os paradigmas de outrora. Ou seja, é possível "ver o pós-modernismo como, em parte, uma espécie de vírus dionísico instalado no modernismo, tentando levá-lo aos extremos da insanidade e da autodissolução, e, em parte, como o secreto princípio interior secreto do modernismo" (CONNOR, 2000, p. 93-94) 
Vê-se, portanto, que a corrente de estilo artístico, que engloba questões culturais e sociais, a qual se convencionou denominar de pós-moderno, apresenta a falta de consenso teórico como uma das suas marcas mais destacáveis. Se por um lado essa realidade possa sugerir uma maior dificuldade para quem pretende analisar um artefato literário sob esse viés, por outro pode oferecer ao crítico o instrumento da polêmica como meio conduzir de modo equilibrado as suas ideias. É sobre essa base de pensamento que se fará a análise do romance "A Expedição Montaigne" (1982) do escritor Antonio Callado.

\section{A Expedição Montaigne e as marcas pós-modernas}

A diegese de narrativas literárias com começo, meio e fim bem delimitados, de modo a facilitar a vida do leitor, parece compor uma técnica que se pode chamar de mais tradicional. A literatura pós-modena, a partir da sua proposta de inovação estética, acaba por romper, de forma mais radical, com a sequência linear dos fatos que formam o enredo das obras. Com isso, não se quer dizer que antes do surgimento do fenômeno pós-moderno não tenha havido construções literárias constituídas por tais características, mas que o pós-modernismo se configura tendo essa pauta como uma das suas marcas mais peculiares.

Tendo como base essa premissa, pode-se enquadrar a obra "A Expedição Montaigne" (1982), de Antonio Callado. O enredo do referido artefato literário tem em seu princípio a apresentação de um dos personagens principais (o índio Ipavu) em um espaço e instante específicos (presídio indígena de Crenaque em Resplendor, Minas Gerais). Todavia, esses elementos da narrativa são descritos e relatados de modo a se fazer referência a outros personagens e ao lugar de origem de Ipavu situados em tempos distintos. Ou seja, desde o começo do enredo, os fatos estão misturados de modo que o leitor precise juntar "as peças de um quebracabeça" para conseguir encontrar um sentido plausível. O narrador onisciente, nesse caso, revela de momento a momento, as lembranças e os desejos de Ipavu em relação à sua antiga aldeia. Situando o referido personagem no presídio de Crenaque, o narrador expressa: 
Ipavu gostava de olhar o relógio parado porque de uns tempos pra cá sentia sempre as costas doendo, na hora de dormir, e levava um tempão esperando que o sopro sossegasse no peito dele, que ele antigamente só sabia que existia do lado de fora mas que agora conhecia por dentro também, de tanto tirar e ver depois abreugrafias e radiografias, as costelas aparecendo feito as varas da gaiola em forma de funil onde ficava o gavião Uiruçu na aldeia camaiurá (CALLADO, 1982, p.9)

Nessas primeiras linhas do romance, o narrador, portanto, estabelece um elo espaço-temporal no qual o personagem Ipavu percorre, através da memória, por ações passadas que se cruzam com o presente. Ocorre, dessa forma, a possibilidade de duas narrativas paralelas que em certo ponto da diegese tem uma intercessão crucial para a compreensão das ações, espaços e tempos multifacetados. Isto é, a imaginação e os desejos de Ipavu são realçados pelo narrador de modo a existir uma linha tênue entre os instantes vividos pelo personagem e aquilo que ele idealizava. A vontade de possuir o gavião-real chamado Uiruçu é uma tônica que perpassa do início ao fim da narrativa. A passagem seguinte mostra que o tempo numa perspectiva cronológica o qual predominou numa narrativa mais tradicional, teve um redirecionamento com as práticas pós-modernas:

Naquele dia, que ia ser o dia da última sesta de paz no presídio, também chamado reeducandário de índios, Ipavu, já quase posto em sossego, balançava a rede pela última vez com o pé direito, o corpo se enroscando em si mesmo, se fechando, tatu-bola, a qualquer recado do mundo lá fora, sem ouvir mais nem zumbido de pium de muriçoca, de vespa ou varejeira, porque começavam a ruflar as asas poderosas de Uiruçu, o gavião-real, que bicava em pleno vôo, por baixo da copa das árvores, o macaco que acabava de arrancar com as garras do galho de ipê, caça dos dois ( CALLADO, 1982, p.10)

Seguindo essa lógica, de acordo com Connor (2000) tanto a estética moderna quanto a pós-moderna tem na questão do tempo uma preocupação relevante. Nas palavras do teórico, o pensamento modernista, no entanto, não consegue romper com a visão cronológica na narrativa na medida em que tempo e espaço ainda são constituídos de certa simetria. De outro modo, "a literatura pósmoderna rompe com isso ao enfatizar o fluxo contingente da temporalidade à custa da estase atemporal da metafísica" (CONNOR, 2000, p.100). 
Com essa marca de enredo que nega a cronologia tradicional da modernidade, a narrativa de Callado apresenta um segundo personagem, que ao lado de Ipavu forma a dupla quixotesca que traduzem o sentido da Expedição Montaigne. Trata-se de Vicentino Beirão, um jornalista influenciado pela cultura francesa que idealiza uma espécie de revolução na qual os índios tomariam tudo aquilo que foi usurpado pelo colonizador. Para isso, ele explode e invade o presídio, onde estava Ipavu, a fim de libertar os índios e, assim, iniciar um levante pelo Brasil afora. A descrição feita pelo narrador é de uma comicidade que lembra, quase de imediato, o famoso personagem de Miguel de Cervantes, Dom Quixote:

\footnotetext{
Era acompanhado do fotógrafo, o jornalista Vicentino Beirão, libertador de silvícolas, antibandeirante, contra-Cabral, não-descobridor, que acabava de invadir o presídio. Como uma pororoca resolvida a dar cabo do Amazonas enfiando no rio água salgada e peixe do mar até os Andes, Vicentino pretendia enfiar uma pororoca de índios pela história branca do Brasil acima, restabelecer, depois do breve intervalo de cinco séculos, o equilíbrio rompido, certo dia, aziago, pelo - as palavras são dele - aquoso e fúnebre ploft de uma âncora de nau, das índias, a rasgar e romper cabaço e regaço das túrgidas água pindorâmicas (CALLADO, 1982, p.11)
}

Como trazia consigo um busto do filósofo francês Michel de Montaigne (1533-1592) o qual, em um dos seus ensaios, defendia que os indígenas não eram bárbaros como se colocava na época, Beirão denomina o seu projeto de Expedição Montaigne. Desse modo, o idealismo ingênuo e cômico de Vicentino Beirão contrasta com a visão de mundo de Ipavu cuja aculturação já estava consolidada. Encantado com a vida do homem branco, o índio aculturado estava longe da pecha colocada pelo quixotismo de Beirão que afirmava ter encontrado no presídio de Crenaque o último dos camaiorá. Na condição de um "Sancho Pança", às avessas, Ipavu, desde o início, demonstra para o jornalista sonhador que sua vontade é se integrar aos modos de vida da sociedade não-indígena. Ou seja,

\footnotetext{
Ipavu não queria por nada deste mundo voltar a ser índio, nu, piroca ao vento, pegando peixe com flecha ou timbó, comendo peixe com milho ou beiju. Queria viver em cidade caraíba, com casas de janela empilhada sobre janela e botequim de parede forrada, do rodapé ao teto, de bramas e antárticas. Índio era burro de morar no mato, beber caxiri azedo, numa cuia, quando podia encher a cara de cerveja e sair correndo na hora de pagar a conta (CALLADO, 1982, p.13)
} 
Dessa forma, fica patente que a ideia e o sentimento de pertencimento a um grupo social no qual se tem origem está sujeito às metamorfoses de uma identidade que não é mais inexorável. Como aponta Hall (2005), o sujeito moderno que estava centrado numa identidade fixa e imutável deixa de existir e dá lugar a novas formas de se relacionar com o mundo. Na modernidade, assim, a razão conseguia explicar a noção de sujeito e colocar os indivíduos em categorias que eram capazes de satisfazer a uma demanda.

Tal ação não é mais viável no mundo pós-moderno, uma vez que a heterogeneidade aflorada nos discursos que instituem os sujeitos inviabiliza qualquer classificação e/ou enquadramento identitário. Para Bauman (2005), a identidade dos indivíduos nesses novos tempos passa por uma crise de valores não havendo, portanto, uma solidez naquilo que o sujeito é ou pretende ser. Nas palavras do crítico polonês ocorre que "as identidades ganharam livre curso e agora cabe a cada indivíduo, homem ou mulher, capturá-las em pleno vôo, usando seus próprios recursos e ferramentas. O anseio por identidade vem do desejo de segurança, ele próprio um sentimento ambíguo" (BAUMAN, 2005, p.35).

A constatação de Bauman (2005) ao reconhecer a fluidez identitária dos sujeitos pós-modernos (ou da modernidade líquida, nos termos dele) é mimetizada na figura do índio Ipavu o qual, inevitavelmente, se opõe a toda uma tradição cultural indígena. Nesse sentido, a inserção na narrativa de outro personagem, o pajé leropé, representa uma referência direta a uma espécie de tradição que, ao se pôr como antagônica às novas formas de relações humanas, está sujeita ao ridículo. Com isso, a maneira como Ipavu se refere ao seu antigo pajé é sempre com desprezo e revolta pela forma arcaica como ele pensava e agia. A oportunidade de voltar à sua aldeia de origem, por intermédio da expedição organizada por Vicentino Beirão, tinha para o camaiorá a única vantagem de retomar o contato com o gavião-real (uiruçu). É interessante, nessa lógica, como o narrador insere, até de forma redundante, os devaneios do referido índio de modo que a narrativa se conduza por um tipo de digressão no tempo e no espaço. Em uma dessas digressões, relata-se o seguinte:

Pajé leropé, o da pálpebra caída, não encarava com Uiruçu, vai ver que de medo de perder a pouca luz que Maivotsinim dava para clarear o escurão daquela alma tão ruim que leropé podia até beber o caldo da 
mandioca brava saído do tipiti e arrotar satisfeito depois, sendo o fato que ele, como a mandioca brava, os dois tinham tirado sustento e corpo da mesma raiz de ruindade. Às vezes o peito de Ipavu doía demais, como naquele dia, naquela noite que ele tinha apanhado de sabre na PM de Carmésia e ele não tinha na frente dele o relógio dos ponteiros se comendo ou se enrabando no meio-dia ou na meia-noite. Foi assim, mesmo, de olho aberto, que ele acabou sonhando que estava aninhando entre as garras de Uiruçu, sem um cuidado que fosse no mundo, porque quando ele doía e gemia baixinho, de dor no peito ou na pranchada do sabre, nem sabia direito, Uiruçu levantava ele um pouquinho nas garras que estavam muito suavezinhas, como se Uiruçu tivesse passado cera de abelha nelas, balançando Ipavu no ar, melhor que rede (CALLADO, 1982, p.17-18)

Antes do início da expedição, propriamente dita, são apresentados, como forma de memórias de Ipavu, alguns fatos, que coadunados, ajudam a entender circunstâncias passadas, presentes e futuras que norteiam toda a diegese do romance. Fale-se, por exemplo que ele adoeceu na tribo (provavelmente de tuberculose), foi levado para o hospital e de lá fugiu para não ter que voltar para a aldeia.

Ao ser preso, o índio que acompanharia Beirão na Expedição Montaigne, conheceu no presídio de Crenaque, Resplendor, Minas Gerais, dois outros índios e o diretor do também chamado reformatório de indígenas (Vivaldo). Sob o consentimento do chefe do presídio, Ipavu e seus companheiros de cela saíam da cadeia rotineiramente para praticarem delitos como furtos. Nesse ponto da narrativa já fica evidente que a representação do índio como figura pura, ingênua e com boa índole (idealizada, principalmente, no Romantismo Brasileiro) passa por um processo de dessacralização.

A personalidade de Ipavu, portanto, é apresentada de forma transparente pelo narrador de modo que fique evidente as flexibilidades de valores e padrões éticos em uma figura que serviu, em outros tempos, como símbolo nacional por representar, de alguma forma, o ideal de integridade humana ou, até mesmo, o homem sem pecado (o adão mítico) enfatizado pelo cristianismo católico que teve hegemonia em terras brasileiras desde o início da colonização portuguesa. 0 contexto da vida do personagem indígena antes da Expedição Montaigne traz, desse modo, alguns indícios de que a aventura proposta pelo jornalista afrancesado não seria compatível com a índole canalha do camaiorá tuberculoso. Para constatar isso, basta compreender que: 
Crenaque era o lar de Ipavu, a casa dele, não a casa da gente ser parida, mas a casada escolhida, apesar dele ter chegado lá depois de surrado por uma coligação de birosqueiros, com duas costelas rachadas, três dentes moles na boca, roído de rato no chão da cadeia. Mas seu Vivaldo tinha sabido ver, naquela posta de camaiorá, o gatuno exemplar, de ninguém botar defeito, que ele soltava todas as noites para o furto regular de cerveja, carne seca, cachaça e goibada, gêneros que, mais os que viam da rapinagem bastante competente de Atroairi e Canoeiro, davam aso três, e a seu Vivaldo que ainda vendia as sobras uma despesa e adega de tuxaua, coronel ou bispo. (CALLADO, 1982, p.14)

O contraste moral e ideológico estabelecido entre o índio Ipavu e o jornalista Vicentino Beirão não impede a realização do projeto idealizado como Expedição Montaigne. Convencido de que não havia outra saída, com interesse de voltar à sua antiga aldeia para roubar Uiruçu (o gavião-real) e depois fugir, Ipavu decidiu acompanhar "o libertador de silvícolas" por uma rota repleta de percalços.

$\mathrm{Na}$ verdade, as ideias revolucionárias propostas por Beirão eram repudiadas por Ipavu justamente por pretenderem fazer o homem branco trocar de posição social (hierárquica) com o povo indígena. A utopia de desmanchar todo um passado histórico que já estava consolidado, isto é, irreversível, movia o pensamento do jornalista. Nesse sentido, se coloca uma relação entre passado e presente através de um interdiscurso que não deixa de ser uma marca pósmoderna na literatura. Beirão faz referência ao descobrimento do Brasil pelos portugueses e à personagem Iracema do romance, de mesmo nome, de José de Alencar. Através do discurso direto, o narrador concede a palavra a Beirão que assim se propõe:

\begin{abstract}
- O que a gente vai fazer, de fato, é levantar, em guerra de guerrilha, as tribos indígenas contra os brancos que se apossaram do território a partir daquele glauco gluglu do ferro da Cabrália caravela logo depois que a figura de proa, lança de S. Jorge e língua de dragão, abriu as coxas e os grandes lábios de mel da bugra Iracema, assim como, se soltando do cabrestante e se enfiando no mar baiano, a âncora de nau de Pedro varou o hímen nheengatu (CALLADO, 1982, p. 30)
\end{abstract}

Resolvidos todos os impasses em relação ao presídio de Crenaque, Vicentino Beirão, tendo como acompanhante o índio Ipavu, iniciou o movimento expedicionário em direção à aldeia de leropé (antigo pajé de Ipavu) localizada, segundo o visionário da expedição, no coração do Brasil. Em momentos de 
digressão, a narrativa acaba revelando alguns confrontos de cultura. No caso, Ipavu "achava leropé um pajé muito bunda e atrasadão, fumando aquele charuto de folha para soprar nos doentes e secando umas merdas dumas ervas do mato, que tanto serviam para dor de dente como pra extrema-unção" (CALLADO, 1982, p.33).

Outro fator que chama a atenção está na construção linguística do romance, sobretudo nas falas diretas do índio camaiorá ou no discurso indireto livre posto pelo narrador na mesma figura. A espontaneidade das palavras, muitas vezes de baixo calão e com fidelidade ao aspecto oral da língua, é uma das marcas linguísticas do romance que se não supera o que foi realizado em obras do modernismo, pelo menos rompe com todos os limites de uma linguagem politicamente correta ou repleta de pudores. Em outras palavras, do ponto de vista estético, uma obra considerada pós-moderna como "A Expedição Montaigne" apresenta, inevitavelmente, também, uma maior liberdade lexical que confronta, justamente, com um posicionamento mais conservador e moral da sociedade.

O romance supracitado se direciona, dessa forma, para um viés estéticoideológico que não respeita os parâmetros tradicionais e, assim, acaba subvertendo princípios não só de uma diegese burguesa linear e mais inteligível como também a preservação de certos valores éticos que antes eram indispensáveis. Tal fenômeno parece estar relacionado ao pensamento de Adorno (2003, p.58) quando propõe que na "transcendência estética reflete-se o desencantamento do mundo". Embora não se refira diretamente à questão pós-moderna na literatura, o teórico alemão sinaliza que o romance, enquanto gênero demandado pela classe burguesa, tenderia a sofrer as mutações decorrentes de uma sociedade que não sustentaria uma visão de mundo homogênea e cujas crises existenciais seriam inevitáveis.

Desse modo, a configuração da obra calladiana, ora em análise, se enquadra em um novo estágio da produção literária no qual não apenas os aspectos sintático-lexicais rompem as amarras que existiam no passado, mas também ratifica, com veemência, a descrença no ser humano e nas suas ideologias. Em decorrência desse fato, não é surpreendente que "o romance não só resiste à interpretação, ele se organiza sistemática e formalmente para impedir um tipo mais antigo de interpretação social e histórica que ele permanentemente pressupõe e mina" (JAMESON, 2006, p.50). 
Com isso, o encaminhamento da expedição, cerne do romance já citado, se direciona para um desfecho que flutua entre o trágico e cômico. Como uma espécie de simulacro da famosa estória de Dom Quixote, a empreitada idealizada pelo visionário Vicentino Beirão teria o fim desastroso, mas capaz de provocar no leitor um riso espontâneo. Depois de percorrer um longo trajeto repleto de peripécias, os personagens chegam a tribo do pajé leropé. Movido pelo único interesse de possuir o gavião-real (Uiruçu), Ipavu retira a ave da gaiola e coloca o "companheiro" Beirão (que estava embriagado e inconsciente) no lugar.

O chefe da tribo foi o primeiro a ver a situação inusitada do expedicionário e, com as suas crenças, não demorou a associar o fato a algum aviso dos deuses. Segundo ele, o gavião-real tinha sido transformado em homem por uma espécie de ordem divina que exigia um sacrifício reparador. Para leropé, então, aquele sujeito preso na gaiola que antes era o gavião real tinha que ser queimado para que todos os males fossem eliminados, ou seja, no pensamento dele ocorria que "candiruleropé trouxe de volta a alma e o corpo numa gaiola, pra queimar, nos dois, todos os casos e acontecimentos! " (CALLADO, 1982, p.114)

Convencidos todos os integrantes da tribo de que a ideia do pajé era plausível, os momentos que antecedem o "sacrifício" de Vicentino Beirão são descritos com certo teor de sarcasmo e ironia. A morte iminente de um homem generoso não traz, pelo menos na narrativa, nenhum apelo sentimental. Em outras palavras, é possível até rir com a desgraça alheia. Esse fato não deixa de ser mais uma característica pós-moderna, talvez o que Jameson (2006) denomina de esmaecimento dos afetos no qual os indivíduos se tornam mais insensíveis perante o sofrimento do outro. Nesse sentido, a maneira debochada como narrador conduz o desfecho do jornalista é algo a se destacar:

Quando Vicentino Beirão acordou ainda conseguiu, naquela da hora das despedidas, pairar por um derradeiro instante nas altitudes severas do pensamento lúcido, por cima dos fumos da cachaça, os quais, diga-se de passagem, e a bem da verdade, iam de certa forma animar as chamas de sua pira. Estas chamas, ateadas pelas velhas da aldeia, as mães camaiorá, já davam uma primeira lambida nas toras de jequitibá, nas tábuas, nas palmas, enquanto os índios em volta, tanoas crianças quanto os guerreiros, erguiam arcos no ar. Vicentino gritou, naturalmente, terá mesmo urrado de ardor e dor quando as palmas incendiadas e os galhos flamejantes o chamuscaram, de início, mas nem terá plenamente apreendido o que como ele se passava antes que sua rápida cocção de ave suspensa no girau, no moquém, simplificasse de maneira decisiva 
qualquer operação mental mais clara de que ele fosse capaz.(CALLADO, p.1982, 121)

O desenlace trágico-cômico desse romance se completa com a morte de Ipavu que ao fugir de canoa na companhia do gavião-real Uiruçu sofre as complicações da tuberculose e falece. O modo como o narrador constrói a cena é, mais uma vez, em um tom de humor que acaba por tornar ridículo o desastre da Expedição Montaigne. Logo, tanto o projeto de Vicentino Beirão que almejava devolver aos índios a autoridade sobre o Brasil (como tinham antes da colonização portuguesa) quanto o desejo de Ipavu de possuir o gavião da sua antiga tribo, têm desfechos infaustos. Destaca-se, então, uma das últimas cenas que corrobora, de certa forma, o desapego sentimental e até o conformismo com os infortúnios:

A canoa, serena, continuava sua marcha rio abaixo, o gavião agora dentro dela, cabeça reta, dando menos a impressão de rasgar o vento com o bico do que de avisar o vento que eles vinham vindo, o gavião, o menino morto, a canoa fúnebre, pra que ele, vento, se abrisse rombudo e oco feito uma redoma e fosse seguindo com eles, protegendo eles (CALLADO, 1982, p.127)

Assim, a constatação do fracasso e a desconstrução de utopias, o que não deixa de ser um sentimento expresso na arte pós-moderna, é ratificado nessa escrita de Antonio Callado. A impossibilidade de reverter alguns processos históricos e a ideia de que a personalidade humana é volúvel, o que significa a construção de identidades heterogêneas e sujeitas a metamorfoses, podem ser considerados na hermenêutica de "A Expedição Montaigne". É óbvio que tal fato não reduz a obra a uma categorização restrita ao fenômeno pós-moderno, todavia uma leitura nesses parâmetros apresenta coerência, uma vez que existem elementos internos e externos ao romance que invitam uma interpretação por esse viés.

\section{Considerações Finais}

A produção literária, vista como um elemento da cultura, não deixa de representar as várias nuances dos anseios da sociedade ao longo do tempo. Diante dessa transcendência em que se instaura a literatura, ocorre a inviabilidade de uma 
pauta restritiva que envolva categorias ou características históricas, estéticas ou ideológicas na condição de chave hermenêutica para a leitura de uma obra.

Nessa perspectiva, o fenômeno pós-moderno, que não se limita ao escopo literário, traz, em sua essência, uma proposta de refutação de valores e crenças que a humanidade cultivou a ponto de forma o que se chama, genericamente, de tradição. Na literatura, o tom pós-moderno parece se expressar com mais subterfúgios devido à natureza abstrata da linguagem.

Ademais, ficou patente que a ótica pós-moderna se configura em um campo teórico marcado por controvérsias. Desde a questão temporal de sua existência até as alterações estético-ideológicas a que se propõe não se estabelecem de forma pacífica. A ideia de uma contestação ao ideário moderno apresenta contradições expostas, por exemplo, por teóricos como Compagnon (2003) e Eagleton (1998). De outra forma, aqueles que fazem apologia ao movimento, como Jameson (2006), enfatizam as novas formas de relação humana nas quais as ações de empatia cedem lugar ao egoísmo hiperbolizado pela visão de mundo capitalista.

Partindo dessa consciência acerca do fazer literário e a sua relação com a conjuntura sociocultural, a análise da obra "A Expedição Montaigne" (1982) de Antonio Callado trouxe implicações críticas e teóricas que revelam a possibilidade de influência em obra, mesmo não cabalmente, de movimentos artísticos e culturais os refletem a configuração da sociedade de determinada época. No caso particular, não bastou constatar o momento específico em que se produziu o romance para enquadrá-lo como pós-moderno, mas perceber as marcas estéticas e ideológicas que permitem relacioná-lo a tal corrente de pensamento.

Nessa lógica, a leitura da obra calladiana supramencionada se direcionou a perceber a construção de um texto marcado pelo rompimento da linearidade diegética no qual tempo e espaço, enquanto elementos imprescindíveis da narrativa, são fragmentados de modo a tornar ainda mais complexa a compreensão pelo leitor,

Outro ponto destacado é o diálogo estabelecido com o passado que remete à origem da nação brasileira através do resgate da figura indígena. O que distingue e dá relevância à "Expedição Montaigne" é a maneira como a narrativa desmitifica 
a construção ideológica feita pelo movimento romântico e aprofunda a visão crítica inicia pelo modernismo.

Assim, a inserção de um índio aculturado e mal caráter em contraposição a um personagem visionário que lembra o espanhol Dom Quixote ou até o brasileiro Policarpo Quaresma constitui um romance paródico cuja ironia e sarcasmo são os contrapesos para a constatação de que o fracasso humano é inevitável ainda mais diante de projetos revolucionários. Se o surgimento do movimento pós-moderno está relacionado da queda humana em um abismo sem volta, a leitura de um romance como esse de Antonio Callado funciona como ratificação.

\title{
THE MONTAIGNE EXPEDITION: A READING UNDER THE POST-MODERN VIENUS
}

\begin{abstract}
Even when it comes to the date of its birth, the artistic-cultural movement called postmodernism brings with it a series of aesthetic changes which do not fail to reflect some ideological positions that seem to gain new configurations but do not escape the inevitable dialogue with the past. It is from this perspective that the present article proposes to make a reading of the novel The Expedition Montaigne (1982) of Antônio Callado. Located in the postmodern context, this work re-read a crucial aspect in the formation of the national identity (the figure of the Indian), which has already been a subject of debate for romantics and modernists. In this sense, we will seek in the diegese proposed by Callado the indications of innovations in the literary making of these new times. Moreover, the very non-consensual theoretical positions around postmodernism deserve to be emphasized from the artifact one wishes to analyze. Among other things, these are the reasons that justify and direct this work. Nazaire (2008), Jameson (2006), Eagleton (1998), Hall (2005), among others, serve as theoretical support for the development of this article.
\end{abstract}

Keywords: The Montaigne Expedition. Ideology. Postmodernism

\section{Referências}

ADORNO, T. W. A posição do narrador no romance contemporâneo. Notas de Literatura I. 34르 ed. São Paulo: Duas Cidades, 2003.

BAUMAN, Z. Identidade. Rio de Janeiro: Zahar, 2005.

CALLADO. A. A expedição Montaigne. Rio de Janeiro: Nova Fronteira, 1982.

COMPAGNON, A. Os cinco paradoxos da modernidade. Belo Horizonte; UFMG, 2003.

CONNOR, S. Cultura pós-moderna: introdução ás teorias do contemporâneo. 4ํㅗำ ED. São Paulo: Loyola, 2000.

EAGLETON, T. Ilusões do pós-modernismo. Rio de Janeiro: Jorge Zahar, 1998.

Revista de Letras JUÇARA, Caxias - Maranhão, v. 03, n. 01, p. 100 - 121, ago. 2019| 120 
HALL, S. A identidade cultural na pós-modernidade. 10ªe ed. Rio de Janeiro: DP\&A, 2005.

JAMESON, F. Pós-modernismo: a lógica cultural do capitalismo tardio. $2^{2}$ ed. São Paulo: Ática, 2006.

NAZÁRIO, L. Quadro histórico do pós-modernismo. In: GUINSBURG, A. M. (org.). O pós-modernismo. São Paulo: Perspectiva, 2008.

Data da Submissão:14/04/2019

Data da Aprovação: 30/05/2019

Revista de Letras JUÇARA, Caxias - Maranhão, v. 03, n. 01, p. 100 - 121, ago. 2019 | 121 